DE DE GRUYTER

OPEN

PESD, VOL. 8, no. 1, 2014

\title{
PRELIMINARY ASSESSMENTS OF THE RELATION: PRECIPITATIONS - WATER - SEDIMENTS WITH REGARD TO SOME ANTHROPIC ACCUMULATIONS IN THE RIVER BASIN OF BAHLUI
}

\begin{abstract}
Minea Ionuţ ${ }^{1}$, Nica Dragoș $^{2}$, BocaBogdan $^{3}$
Key words: statistical correlations, determination reports, reservoirs, effects on silting processes.

Abstract. An important aspect of the statistical assessment of the correlation between precipitations - water and sediments is the way these parameters are assessed by means of statistical correlations of the type $\mathrm{Q}=\mathrm{f}(\mathrm{Pp}), \mathrm{R}=\mathrm{f}(\mathrm{Q})$ or $\mathrm{R}=\mathrm{f}(\mathrm{Pp})$. Following the analysis of the three types of correlations the conclusion that water and sediment flows depend much on the quantity of water that falls may be reached. The accumulations however introduce some modifications of the water run-offs depending on the intended use. In order to carry out detailed analyses of some processes related to the evolution of channel bed or reservoirs silting, the equations may be extrapolated to the entire river basin.
\end{abstract}

\section{Introduction}

While in the case of the water run-off, the water resources management enables the existence of a relative balance between the water volume entering the reservoir by means of the tributaries and the water flowing out of the reservoir by means of the natural drainage channel, the situation is different with the sediments run-off. Most of the solid run-off (suspended particles and carried bed load) is

\footnotetext{
${ }^{1}$ Lecturer Phd, "Alexandru Ioan Cuza" University of Iași ionutminea1979@yahoo.com

${ }^{2}$ Assistant. Phd, "Alexandru Ioan Cuza" University of Iași

${ }^{3}$ phd. stud. "Ion Ionescu de la Brad", University of Agricultural Sciences and Veterinary Medicine of Iași
} 
"abstracted" during accumulation and silts progressively throughout time (Ichim, Rădoane, 1986, Giurmă, 1997, Rădoane, 2005).

An important aspect of the statistical assessment of the correlation between precipitations-water-sediments is the way these parameters are assessed by means of the monitoring systems (meteorological stations or rain gauges and hydrometers, respectively). Taking into account that starting with the 50's various water projects in the Bahlui river basin have been carried out, many stations have also undergone alterations of the observation and location. In this case certain parameters shall be assessed on the basis of the data collected from certain points located outside the water areas in order to integrate the findings in our study. In so far the relation precipitations-water-sediments has been analyzed for two accumulations: Pârcovaci located in the Northwest side of the basin which is almost entirely covered by forests, and Ciurbești, located at $20 \mathrm{~km}$ South from the city of Iași and where the drainage basin is seriously affected by the current geo-morphological processes (surface and bulk erosion, landslides, etc).

\section{Database and methodology}

The correlations are assessed on the basis of the data collected, in the case of Pârcovaci, from the hydrometers Vama cu Tablă (located upstream from the accumulation) and Cârjoaia (located in the basin of Măgura river in similar geographic conditions), and in the case of Ciurbești, on the basis of the data collected from the Ciurbești hydrometer. Moreover the impact of the accumulations on the water flow shall also be taken into account and assessed based on the relation:

Qnat $=$ Qmas $\pm \Delta$ Qamonte,

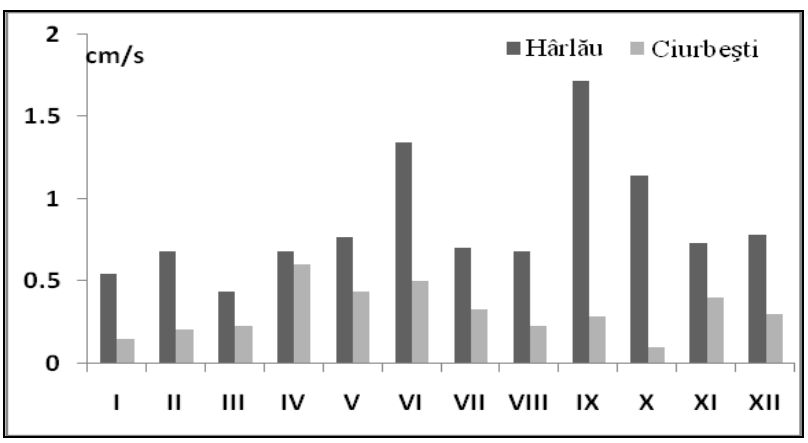

Fig. 1 Relation Qmăs/ Qnat in the case of the hydrometers concerned (average monthly values for 1950-2012) 
In the case of Pârcovaci accumulation, Qmăs/Qnat exceeds the average of $0.44 \mathrm{~m}^{3} / \mathrm{s}$, and in the case of Ciurbești accumulation, $0.30 \mathrm{~m}^{3} / \mathrm{s}$ (Fig. 1).

Statistical correlations such as $\mathrm{Q}=\mathrm{f}(\mathrm{Pp}), \mathrm{R}=\mathrm{f}(\mathrm{Q})$ or $\mathrm{R}=\mathrm{f}(\mathrm{Pp})$ have been carried out for each and every accumulation to identify the connection between these hydrologic parameters in order to perform detailed analyses for some processes related to the evolution of the river bed or the reservoirs silting.

\section{Correlation water - atmospheric precipitations $Q=\mathbf{f}(\mathbf{P p})$}

Generally this correlation is showed by analyzing the data collected from the points monitoring the climatic and hydrologic parameters in the same area. Therefore in the case of Ciurbești accumulation for which there are common data strings related to precipitations and water flows measured within 1978 - 2011, the direct correlation between the parameters $\left(r^{2}=0.63\right)$ is quite strong, provided the years with maximum and minimum quantities of precipitations, are excluded (Fig. 2).

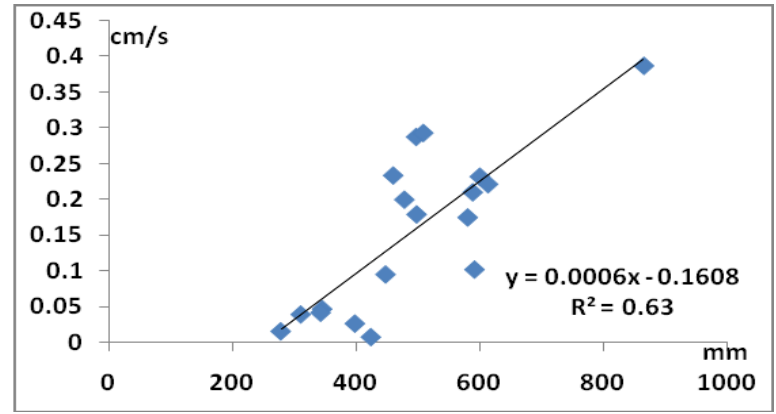

Fig. 2.Correlation $\mathrm{Q}=\mathrm{f}(\mathrm{Pp})$ for Ciurbești accumulation (period 1978-2011)

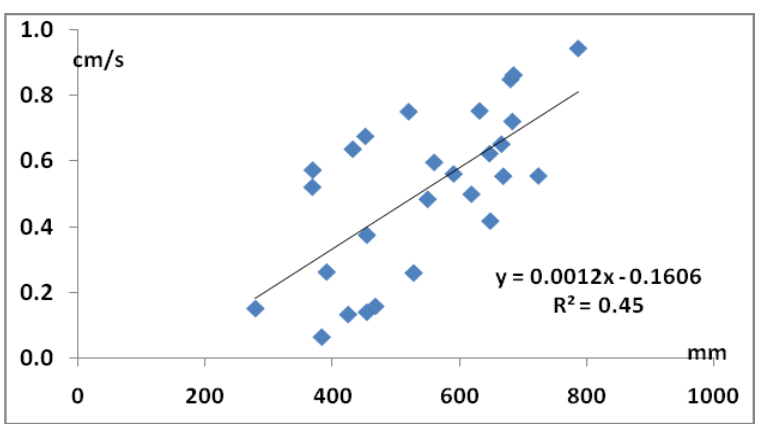

Fig. 3.Correlation $\mathrm{Q}=\mathrm{f}(\mathrm{Pp})$ for Pârcovaci accumulation (period 1978-2011) 
In the case of Pârcovaci accumulation the data string is slightly longer (from 1971 to 2011). Therefore the values of the correlation coefficient $r^{2}$ are lower $(0.45$, provided the years with maximum and minimum quantities of precipitations are excluded) due to local variations in elevation (higher altitude) and vegetation (wooded upstream basin) (Fig. 3).

By analyzing the values that result from the correlation $Q=f(P p)$ the conclusion that water flows depend much on the quantity of water that falls may be reached. However the accumulations introduce some modifications of the water run-offs depending on the intended use (volume of water abstracted for various usages, especially in the case of Pârcovaci accumulation).

\section{Correlation sediment - water $R=\mathbf{f}(\mathbf{Q})$}

For what concerns the connection between the suspended load $(\mathrm{R}, \mathrm{kg} / \mathrm{s})$ and water $\left(\mathrm{Q}, \mathrm{m}^{3} / \mathrm{s}\right)$, the hydrologic measures have been found to be relatively proportional in the case of Bahlui river basin also. Particularly interesting is the fact that for the same water flows, the sediments vary from one month to another or between floods depending on the geo-morphological evolution of the bed channel which is either in the phase of aggradation or silting. In our country a direct correlation between the water and sediment has been highlighted as:

$\log \mathrm{R}=1.25 \log \mathrm{Q}$ (Diaconu, 1971),

and has been subsequently extrapolated to:

$$
\mathrm{R}=\mathrm{AQ}^{\mathrm{n}},
$$

(where $\mathrm{A}$ and $\mathrm{n}$ are coefficients specific to each river basin) (Diaconu, Şerban, 1994). Concerning the Bahlui river basin the following relation has been obtained by correlating the water and sediments from the hydrometers which reported significant databases (Fig.4) (Minea, 2012):

$$
\log \mathrm{R}=1.47 \log \mathrm{Q},
$$

Since there are only 3 points of monitoring the sediments in the Bahlui river basin: Cârjoaia (on Măgura river), Târgu Frumos (on Bahlueț river) and Iași (on Bahlui river), we will focus in our analysis on the data collected from the first monitoring point and extrapolate our conclusions to Pârcovaci accumulation area which is located in similar geographic conditions. 


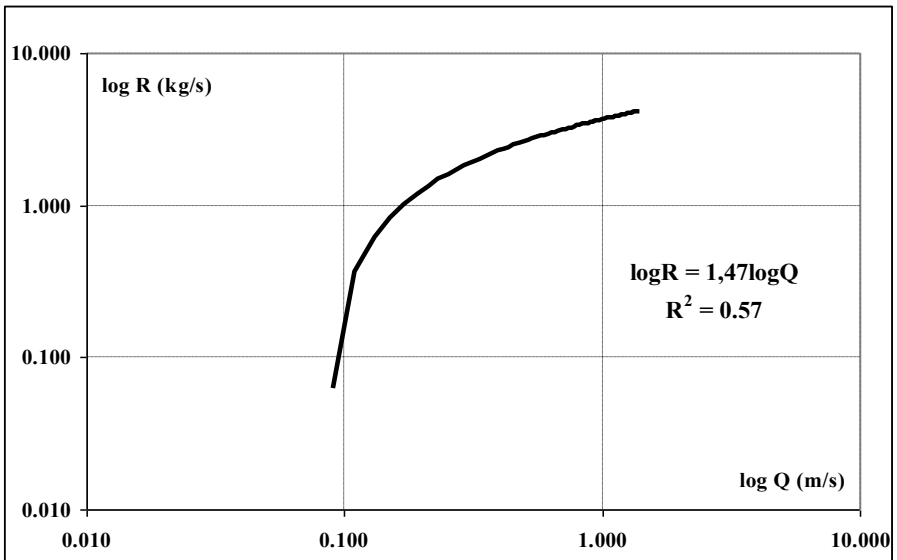

Fig.4 Connection between the average suspended load $(\mathrm{R})$ and water (Q) in the case of Bahlui river basin (Minea, 2012)

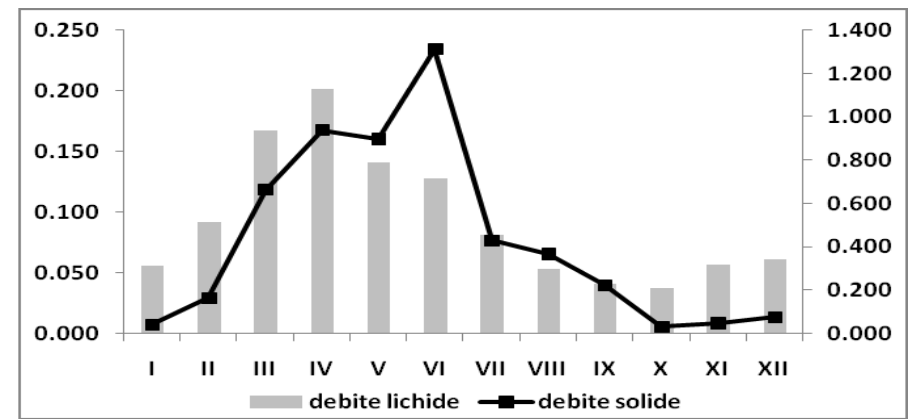

Fig. 5 Water and sediment annual regime for Cârjoaia hydrometer

In terms of flow regime showed in Fig 5 a certain gap between maximum monthly water and sediment flows is to be noticed. The gap results from the different carrying capacities recorded in March-April which is conditional on the bed load from the catchment area.

The highest values of sediments are recorded in May amid increasing bed load carrying capacity by the rapid floods occurring in this month due to significant precipitation falls (sometimes exceeding $1001 / \mathrm{m}^{2}$ in less than 24 hours). The multiannual variation of the water and sediment flows indicates a decreasing trend for both parameters which is stronger in the case of sediments and weaker in terms of gradient in the case of water. 
Concerning the statistical correlation between the above mentioned parameters the following relation has been obtained according to the methodology described (Fig. 6):

$$
\log \mathrm{R}=1.57 \log \mathrm{Q}
$$

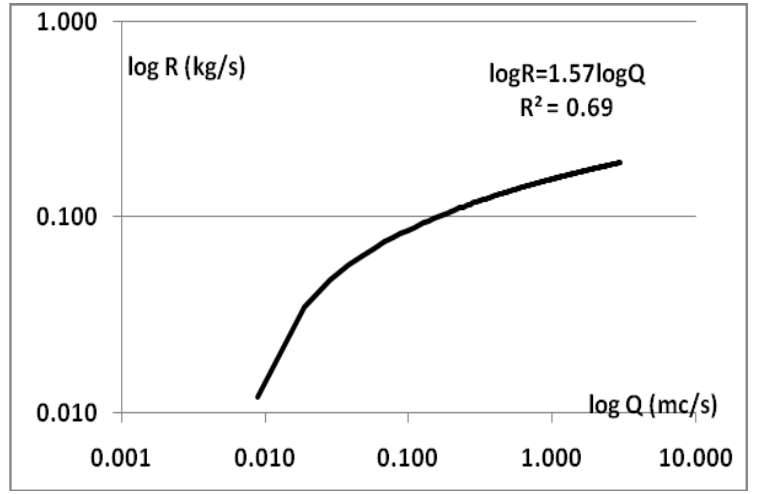

Fig. 6 Connection between the average suspended load (R) and water

(Q) in the case of Cârjoaia river basin

The relation may be used to model the sediments of the rivers in the drainage basin of Bahlui river, including the rivers reaching the Pârcovaci accumulation. In the absence of data related to Ciurbești accumulation, the relation $\log \mathrm{R}=1.47 \log \mathrm{Q}$ (Minea, 2012) may be used which is valid for the entire basin of the Bahlui river.

\section{Correlation sediments - precipitations $R=\mathbf{f}(\mathbf{P p})$}

The multi-annual variation of the suspended load is conditional on the water regime and atmospheric precipitations. Thus in the case of Cârjoaia hydrometer, within 1981-2005, in years 1988, 1991, 1996 the values of the annual average suspended loads are high (over $2 \mathrm{~kg} / \mathrm{s}$ ), and in years 1986, 1987, 1990, 2004 the values of the annual average suspended load are low (below $0.100 \mathrm{~kg} / \mathrm{s}$ ). Generally, the highest values correspond to years with large amounts of precipitations (e.g. in year 1991, the suspended bed load of 2,8 kg/s was recorded at Cârjoaia hydrometer and the amount of monthly precipitations in the case of Hârlău hydrometer was 825 $\mathrm{mm}$ ), and the lowest values to the years with poor precipitations (Cârjoaia hydrometer, years 1986, 1987 and 1994, suspended bed loads records: $0.096 \mathrm{~kg} / \mathrm{s}$, $0.081 \mathrm{~kg} / \mathrm{s}, 0.085 \mathrm{~kg} / \mathrm{s}$ respectively, and the annual amounts of precipitations recorded at Hârlău rain gauge: $483.7 \mathrm{~mm}, 460.9 \mathrm{~mm}, 410.7 \mathrm{~mm}$, respectively).

Generally there is a direct correlation between the annual amount of precipitations and the suspended bed loads carried by a river (Fig. 7). However the correlation is dependent on the degree of disaggregation of rocks and intensity of 
the geo-morphological processes taking place at the surface of the considered drainage basin.

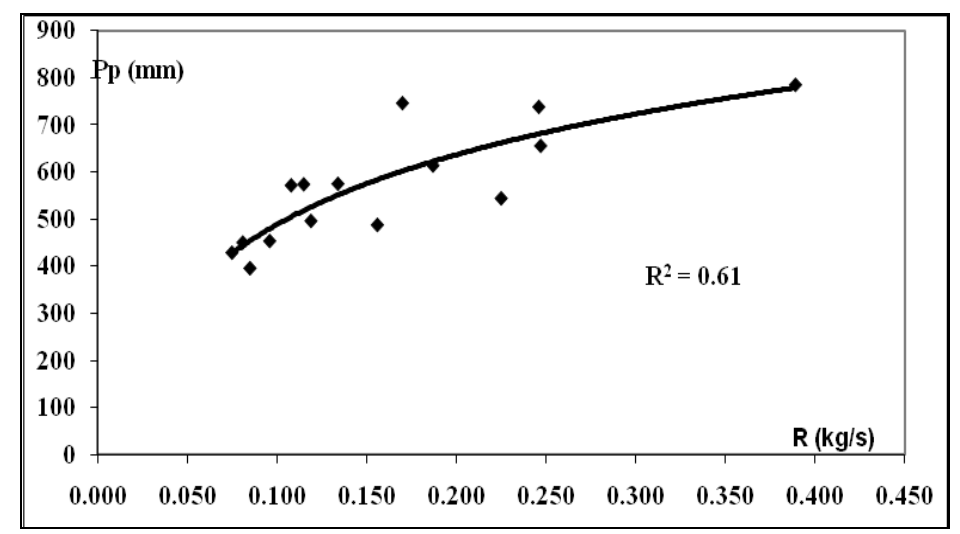

Fig. 7 Connection between the annual amount of precipitations and suspended bed loads recorded at Târgu Frumos hydrometer (Bahlueţ river)

\section{Conclusions}

Following the analysis of the three types of correlations the conclusion that water and sediment flows depend much on the quantity of water that falls may be reached. The accumulations however introduce some modifications of the liquid run-offs depending on the intended use (volume of water abstracted for various usages, especially in the case of Pârcovaci accumulation).

Although the value of the specific annual average suspended bed loads is close to the country average value (2.06 t/ha.year) and with the view to maintain a moderate erosion and a low bed load as reasonably possible in this basin, it is necessary to commence adequate arrangement programs for lands, including increasing the forestry plantation on ploughed flanks and inter-rivers with slopes greater than $10-20 \%$.

\section{References}

Bucur D., Savu P., 2006 Considerations for the Design of Intercepting Drainage for Collecting Water from Seep Areas, Journal of Irrigation and Drainage Engineering, Reston, SUA, vol. 132, Issue 6, 597-599.

Diaconu C., Serban P. 1994 Hydrological Summarises and Regionalisation, Technical Publishing House

Drobot R. 1997, Statistical Basis of Hydrology, Didactic and Pedagogical Publishing House, Bucharest 
Giurma I. 1997, Reservoir Silting, H.G.A. Publishing House, Bucharest

Ichim I. Rădoane Maria (1986), Effects of Dams on the Landscape Dynamics, Academic Publishing House R.S.R., Bucharest.

Minea I., 2012, Bahlui River Basin - Hydrologic Study, "Al. I. Cuza" University Publishing House Iaşi.

Nica D., Minea Ionut, (2005) - Surface Hydrological and Geological Structures in the Middle Basin of Bahlui River, „Dimitrie Cantemir” Geographical Workshop Works, no 25, p. 159-166, Iaşi, ISSN 1222-989X

Pandi G. 1997, Energetic Concept of Formation and Carriage of Suspended Bed Loads. Application in NV side of Romania, University Press Publishing House, Cluj-Napoca.

Pantazică Maria 1974, Hydrograph of the Field of Moldavia, Junimea Publishing House, Iaşi.

Rădoane Maria, Rădoane N. 2005, Dams, Sediment Sources and Reservoir Silting in Romania, www.elsevier.com/locate/geomorf.

Savin Nicoleta 1998, Research on the Influence of some Accumulations Progressive Silting Processes on Large Water Functioning, with References to Bahlui River Basin, Ph. D. Thesis, „Gh.Asachi” Technical University Publishing House, Iaşi.

Savu P., Bucur D., 2009, Regulation of River Flows, Ion Ionescu de la Brad Publishing House, Bucharest, 2009, Iaşi. 